\title{
The emerging role of insulin-like growth factor 1 receptor (IGF1r) in gastrointestinal stromal tumors (GISTs)
}

Maria A Pantaleo ${ }^{1,2^{*}}$, Annalisa Astolfi ${ }^{1,2}$, Margherita Nannini ${ }^{1}$, Guido Biasco ${ }^{1,2}$

\begin{abstract}
Recent years have seen a growing interest in insulin-like growth factor 1 receptor (IGF1R) in medical oncology. Interesting data have been reported also on IGF1r in gastrointestinal stromal tumors (GISTs) especially in children and in young adult patients whose disease does not harbour mutations on KIT and PDGFRA and are poorly responsive to conventional therapies. However, it is too early to reach conclusions on IGF1R as a novel therapeutic target in GIST because the receptor's biological role is still to be defined and the clinical significance in patients needs to be studied in larger studies. We update and comment the current literature on IGF1R in GISTs and discuss the future perspectives in this promising field.
\end{abstract}

\section{Introduction}

Recent years have seen a growing interest in insulin-like growth factor 1 receptor (IGF1R) in medical oncology. IGF1R is a tyrosine kinase receptor that binds both IGF1 and IGF2 [1]. After ligand binding, the tyrosine kinase domain is activated and stimulates the intracellular signaling pathways that control the proliferation rate and apoptosis (Figure 1). Two key signal-transduction networks have been identified: GPTase Ras-Raf-ERK/ MAPK and PI3K-AKT/mTOR [2]. The IGF system plays a key role in the growth and development of normal tissue. However, aberrations of this molecular pathway such as overexpression of IGF1R, elevated plasma levels of IGF1, loss of IGF2 imprinting, or genetic polymorphisms of the gene encoding IGF1 have been found in many cancers, affecting multiple aspects of malignancy such as tumor growth and metastases $[3,4]$. The biologic role of the IGF system in rhabdomyosarcomas, neuroblastomas, osteosarcomas and soft-tissue sarcomas has been widely demonstrated by preclinical and clinical evidence [5-20]. The IGF1R pathway has also been shown to exhibit cross-talk with a number of other signaling pathways such as EGFR and HER2, suggesting a possible role in mediating resistance to drugs targeting

\footnotetext{
* Correspondence: maria.pantaleo@unibo.it

'Department of Hematology and Oncological Sciences "L.A.Seragnoli", S.

Orsola-Malpighi Hospital, University of Bologna, Italy

Full list of author information is available at the end of the article
}

these molecules $[21,22]$. Therefore IGF1R has been investigated in cancer therapy and strategies for its inhibition in sarcoma have already been reported [23-26]. Inhibition of IGF1R affects Ewing's sarcoma cell growth in vivo $[27,28]$ and seems to sensitize sarcoma cells to conventional agents by a synergistic interaction, suggesting a therapeutic combination approach $[29,30]$. Although the family of sarcomas is the most investigated field, aberrant IGFIR signaling has been implicated in other solid tumors, including lung, breast and colon cancer [31-35]. Interesting data have been reported on IGF1R in gastrointestinal stromal tumors (GISTs) [36-40]. Current literature on IGF1R in GISTs needs to be updated with a discussion on future perspectives in this field.

As is well known, GISTs are characterized by the abnormalities of the KIT and PDGFRA receptors that represent the key oncogenic event and most important therapeutic target [41-45]. In a small subset of patients the disease does not present any mutation and is defined as wild-type (WT). The mutational status of KIT and PDGFRA affects response to tyrosine kinase inhibitors and confers primary or secondary resistance $[44,45]$. Recently, IGF1R has emerged as a novel molecular signaling pathway other than KIT and PDGFRA on GISTs [36-40]. Tarn and colleagues evaluated IGF1R with SNPs array, FISH and realtime PCR at genomic level, and with western blotting (WB) and immunohistochemistry (IHC) at protein 


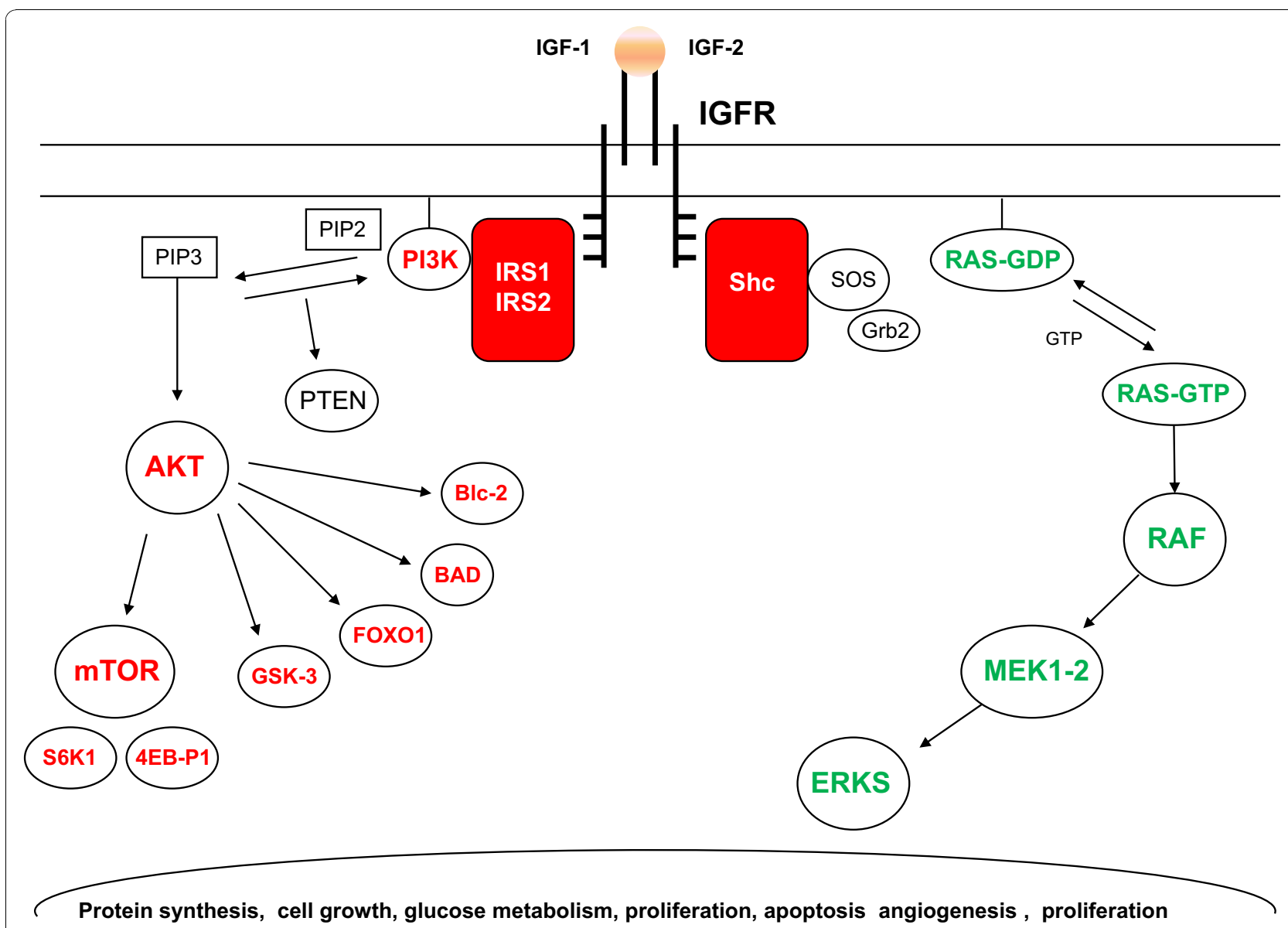

Figure 1 IGF1R pathway.

level [36]. By SNPs analysis they found that the IGF1R gene was amplified especially in WT GISTs compared with mutant GISTs, including a pediatric case. To determine whether enhanced expression of IGF1R is associated with gene amplification, they evaluated IGF1R gene copy number in mutant and WT GISTs using a genomic-based quantitative PCR assay. Seven of the 10 WT GISTs had the IGF1R amplification (copy number range, 2.5-4 copies) compared with only 5 out of 18 mutant GISTs $(\mathrm{P}=0.04)$. IGF1R gene amplification was also confirmed by FISH. No mutations in IGF1R gene were found in the WT GISTs. The protein level was abundantly expressed only in WT GIST by WB and IHC (Cell Signaling antibody). Agaram and colleagues evaluated IGF1R in 17 patients as gene expression profiling (mRNA level) and found that it was up-regulated in children and young adults (patients $<30$ years old) [37]. We examined the IGF1R status in 8 patients with gastric GIST [38]. IGF1R was studied as gene expression profiling performed with Affymetrix GeneChip HG-U133 Plus 2.0 arrays and as genomic copy number with SNP array analysis Affymetrix Genome Wide Human SNP 6.0 arrays, and at protein level with
IHC (Santa Cruz Biotechnology Inc). The unsupervised analysis of gene expression profiling in our patients merged with a data set from a gastric GIST showed that IGF1R was up-regulated in two young patients $(<30$ years old) with both WT disease and metastases at diagnosis, and was confirmed by WB and IHC. SNPs array analysis of the genomic copy number showed that neither of the 2 young patients had tumors with IGF1R amplification. More recently, Janeway and colleagues studied IGF1R with WB, SNP and FISH and found a strong expression of the receptor in 8 out of 9 WT pediatric GISTs [39]. By SNP analysis, none of the pediatric WT GISTs had IGF1R amplification. To validate the SNP data, FISH was done in two patients and in one additional pediatric WT GIST for which there was insufficient fresh frozen specimen for SNP analysis and no gene amplification was documented in any of the 3 cases. Lastly, Braconi and colleagues evaluated IHC expression of IGF1R (Santa Cruz antibody) and its ligands IGF1 and IGF2 in 94 patients [40]. They found that the IGF1R was strongly expressed in most cases both WT and mutant, but the ligands showed different levels of expression. 


\section{Discussion}

Despite the above studies, it is too early to reach conclusions on IGF1R as a novel therapeutic target in GIST. Firstly, the data from these studies are related to different levels of biological information, and secondly they were obtained using different assays, different antibodies and different scores. In addition, although we cannot generalize, longstanding experience of EGFR in colorectal cancer as a target and molecular predictor of EGFR inhibitors should be considered before talking about novel targets in medical oncology [46,47]. Moreover, to date few data have been reported on IGF1R in GISTs and the receptor's true role in the pathogenesis of the disease remains to be defined. As a consequence, the clinical implications such as the correlation with mutational receptors status, clinical outcome, prognosis, therapeutic responsiveness or the exact GIST population with IGF1R deregulation require further investigation.

First of all, the mechanism by which IGF1R is strongly expressed in WT GISTs has not been identified. Low level amplification in 6 WT GISTs was reported only by Tarn and colleagues [36], whereas the other reports on IGF1R $[38,39]$ and SNP-array data $[48,49]$ that collectively analyzed 26 pediatric or young adult WT GIST cases showed no gain at chromosome 15. Hence it is conceivable that IGF1R amplification represents a rare event in WT GISTs, and that IGF1R overexpression is reasonably sustained by other mechanisms. The lack of genomic amplification is not surprising, since IGF1R is not generally found amplified in human tumors $[1,24]$. Many mechanisms contribute to IGF1R overexpression in sarcomas [24] such as receptor upregulation or overexpression of ligands driven by multiple mechanisms like fusion genes (PAX3-FKHR; EWS-WT1; EWS-FLI1), loss of imprinting (LOI) of IGF2, or loss of tumor suppressor genes (WT1, PTEN, p53). IGF2 LOI deserves further investigation in WT GISTs because it is an important mechanism in many pediatric solid tumors, and because ligand expression is found in WT GISTs [40].

The most exciting future perspectives are first to study the biological role of IGF1R in GISTs in in vitro and in vivo models, and second to investigate the receptor's clinical significance further using ex-vivo analyses (IHC, gene expression, SNP, etc) in larger series of patients. About the biological role, notwithstanding the very high expression of IGF1R in GIST carrying a wild type KIT and PDGFRA status, suggesting a possible role as a therapeutic target, almost no experimental data are available on the functional role and oncogenic relevance of this receptor in GIST tumors. The only data were reported by Tarn and colleagues who treated GIST-T1 and GIST 882 cell lines with the IGF1R inhibitor NVP-AEW541, measuring an
$\mathrm{IC}_{50}$ of $3.7-3.9 \mu \mathrm{M}$ [36]. Albeit encouraging, this result is not predictive of any activity in GIST WT tumors, since these cell lines poorly express IGF1R, harbor KIT mutations and are dependent on aberrant KIT signaling for proliferation and survival. In addition, the $\mathrm{IC}_{50}$ concentration is suggestive of the inhibition of tyrosine kinase targets other than IGF1R [50]. IGF1R signaling was blocked in many other types of sarcomas to explore its role in cell proliferation and survival in vitro, and tumor growth, invasion and metastasis in vivo in animal models [25]. Unfortunately preclinical studies assessing the relevance of IGF1R in GISTs are hampered by the lack of a suitable in vitro model of WT GIST. To overcome this problem KIT-mutant GIST cell lines could be infected with IGF1R vectors inducing IGF1R expression and analyzing its effect on cell growth, proliferation, apoptosis and response to agonists (IGF1 and IGF2) and IGF1R-inhibitors or antibodies [51]. IGF1R induction could also be coupled with KIT downregulation to explore the relationship between the two oncogenic signaling pathways. IGF1R-transfected GIST cell lines could also be used in vivo in suitable xenograft animal models to test the efficacy of different IGF1Rinhibitors and the effect of the combination with standard front line therapies [52]. These analyses are particularly necessary to confirm the putative oncogenic role of IGF1R in WT GISTs. Indeed the possibility that IGF1R is not a tumor-specific target, but just a stage-specific differentiation marker of interstitial cell of Cajal (ICC) precursors cannot be ruled out, since a recent work by Lorincz and colleagues showed that ICC precursors are a rare IGF1Rpositive, $\mathrm{Kit}^{(\text {low })}, \mathrm{CD} 44^{(+)}, \mathrm{CD} 34^{(+)}$Insr $^{(+)}$cell population, retained in postnatal life, that is dependent on IGF signaling for survival and differentiation [53]. The absence of IGF1R activating mutations or genomic amplifications in WT GIST does not offer even indirect support of a dominant oncogenic role [37-39]. Besides functional in vitro and in vivo studies, in-depth analysis of WT GISTs genomic and transcriptomic profile by microarray or next generation sequencing techniques will help to clarify IGF1R's role as a marker or therapeutic target, and the mechanism of its over-expression in this rare subtype of GIST that is poorly responsive to conventional therapies $[37,48,49]$.

If preclinical functional studies demonstrate the pathogenetic role of IGF1R in WT GISTs, the IGF axis blockade may be beneficial in the treatment of GIST. However, in-depth analysis of the IGF axis in GISTs is mandatory, since ligand signaling could also be driven by other receptors like insulin receptor isoform A (IRA), that is especially overexpressed in cancer [54], and whose expression and function have not been investigated in GISTs. Commonly, membrane receptor blockade can be achieved with monoclonal antibodies that block the extracellular domain, or with tyrosine kinase 
inhibitors that block the intracellular tyrosine kinase. In theory, if they work both should block receptor activation, and thereby block the intracellular pathways. Of course, direct inhibition of the molecules of these pathways, such as MAPK or PI3K or mTOR, is a potential therapeutic option especially because no amplification or kinase mutation have been identified for IGF1R. Moreover, this strategy may have an enhanced antitumor effect since MAPK, PI3K or mTOR may also be activated by KIT and PDGFRA receptors and may overcome KIT and PDGFRA-dependent imatinib resistance [55].

Glycemic derangements related to insulin-like growth factors such as the pro-IGF-IIE and insulin-like growth factor-binding proteins have been described in GISTs, and they may become more important in patient management because of a potential cross-reactivity between IGF1R and the insulin receptor [56-59]. Even though metabolic derangements are uncommon and no data are available on what might happen to glucose metabolism after administration of IGF1R-targeted drugs, great attention should be paid to these clinical aspects and caution exerted during therapeutic IGF1R inhibition in GIST.

\section{Conclusions}

In conclusion, a novel signaling pathway other than KIT and PDGFRA is emerging in GISTs, and more preclinical studies are needed to disclose its biological role. Larger population studies are warranted to identify patients who may benefit from IGF1R inhibitors such as children or also young adult WT patients. Moreover, these analyses should be centralized as was done for KIT and PDGFRA mutational status especially because GIST is a rare disease.

\section{Abbreviations}

(IGF1R): Insulin-like growth factor 1 receptor; (GISTs): Gastrointestinal stromal tumors; (PDGFRA): Platelet derived growth factor receptor; (WB): Western blotting; (IHC): Immunohistochemistry; (WT): Wild-type.

\section{Author details \\ 'Department of Hematology and Oncological Sciences "L.A.Seragnoli", S. Orsola-Malpighi Hospital, University of Bologna, Italy. ${ }^{2}$ Interdepartmental Centre of Cancer Research "G. Prodi", University of Bologna, Italy.}

\section{Authors' contributions}

MAP and GB: concept and design. MAP, AA and MN: writing. AA and MN: literature analysis. All authors gave final approval.

\section{Competing interests}

The authors declare that they have no competing interests.

Received: 19 May 2010 Accepted: 15 November 2010 Published: 15 November 2010

\section{References}

1. Pollak MN, Schernhammer ES, Hankinson SE: Insulin-like growth factors and neoplasia. Nat Rev Cancer 2004, 4:505-18.
2. Tao Y, Pinzi V, Bourhis J, Deutsch E: Mechanisms of diseases: signalling of the insulin-like Growth Factor 1 Receptor pathway-therapeutic perspectives in cancer. Nature Clin Pract Oncology 2007, 4:591-602.

3. Ryan PD, Goss PE: The emerging role of insulin-like growth factor pathway as therapeutic target in cancer. The Oncologist 2008, 13:16-24.

4. Sachdev D, Zhang X, Matise I, Gaillard-Kelly M, Yee D: The type I insulinlike growth factor receptor regulates cancer metastasis independently of primary tumor growth by promoting invasion and survival. Oncogene 2010, 29:251-62

5. Kappel CC, Velez-Yanguas MC, Hirschfeld S, Helman LJ: Human osteosarcoma cell lines are dependent on insulin-like growth factor I for in vitro growth. Cancer Res 1994, 54:2803-7.

6. Savage SA, Woodson K, Walk E, Modi W, Liao J, Douglass C, Hoover RN, Chanock SJ, National Osteosarcoma Etiology Study Group: Analysis of genes critical for growth regulation identifies Insulin-like Growth Factor 2 Receptor variations with possible functional significance as risk factors for osteosarcoma. Cancer Epidemiol Biomarkers Prev 2007, 168:1667-74.

7. Scotlandi K, Benini S, Sarti M, Serra M, Lollini P-L, Maurici D, Picci P, Triche TJ, Baldini N: Insulin-like growth factor I receptor-mediated circuit in Ewing's sarcoma/peripheral neuroectodermal tumor: a possible therapeutic target. Cancer Res 1996, 56:4570-4.

8. Toretsky JA, Kalebic T, Blakesley V, LeRoith D, Helman L: The insulin-like growth factor-I receptor is required for EWS/FLI-1 transformation of fibroblasts. J Biol Chem 1997, 272:30822-7.

9. Friedrichs $\mathrm{N}$, Küchler J, Endl E, Koch A, Czerwitzki J, Wurst P, Metzger D, Schulte JH, Holst MI, Heukamp LC, Larsson O, Tanaka S, Kawai A, Wardelmann E, Buettner R, Pietsch T, Hartmann W: Insulin-like growth factor-1 receptor acts as a growth regulator in synovial sarcoma. $J$ Pathol 2008, 216:428-39.

10. Van der Ven LT, Roholl PJ, Gloudemans T, Van Buul-Offers SC, Welters MJ, Bladergroen BA, Faber JA, Sussenbach JS, Den Otter W: Expression of insulin-like growth factors (IGFs), their receptors and IGF binding protein-3 in normal, benign and malignant smooth muscle tissues. $\mathrm{Br} J$ Cancer 1997, 75:1631-40.

11. Burrow S, Andrulis IL, Pollak M, Bell RS: Expression of insulin-like growth factor receptor, IGF-1, and IGF-2 in primary and metastatic osteosarcoma. J Surg Oncol 1998, 69:21-27.

12. Xie Y, Skytting B, Nilsson G, Brodin B, Larsson O: Expression of insulin-like growth factor-1 receptor in synovial sarcoma: association with an aggressive phenotype. Cancer Res 1999, 59:3588-3591.

13. de Alava E, Panizo A, Antonescu CR, Huvos AG, Pardo-Mindán FJ, Barr FG, Ladanyi M: Association of EWS-FLI1 type 1 fusion with lower proliferative rate in Ewing's sarcoma. Am J Pathol 2000, 156:849-855.

14. Scotlandi K, Avnet S, Benini S, Manara MC, Serra M, Cerisano V, Perdichizzi S, Lollini PL, De Giovanni C, Landuzzi L, Picci P: Expression of an IGF-I receptor dominant negative mutant induces apoptosis, inhibits tumorigenesis and enhances chemosensitivity in Ewing's sarcoma cells. Int J Cancer 2002, 101:11-16.

15. Busund LT, Ow KT, Russell P, Crowe PJ, Yang JL: Expression of insulin-like growth factor mitogenic signals in adult soft-tissue sarcomas: significant correlation with malignant potential. Virchows Arch 2004, 444:142-148.

16. Ahlen J, Wejde J, Brosjo O, von Rosen A, Weng WH, Girnita L, Larsson O, Larsson C: Insulin-like growth factor type 1 receptor expression correlates to good prognosis in highly malignant soft tissue sarcoma. Clin Cancer Res 2005, 11:206-216.

17. El-Badry OM, Minniti C, Kohn EC, Houghton PJ, Daughaday WH, Helman LJ: Insulin-like growth factor II acts as an autocrine growth and motility factor in human rhabdomyosarcoma tumors. Cell Growth Differ 1990, 1:325-31.

18. Zhan S, Shapiro DN, Helman LJ: Activation of an imprinted allele of the insulin-like growth factor II gene implicated in rhabdomyosarcoma. J Clin Invest 1994, 94:445-8.

19. Shapiro DN, Jones BG, Shapiro LH, Dias P, Houghton PJ: Antisensemediated reduction in insulin-like growth factor-I receptor expression suppresses the malignant phenotype of a human alveolar rhabdomyosarcoma. J Clin Invest 1994, 94:1235-42.

20. Liu X, Turbyville T, Fritz A, Whitesell L: Inhibition of insulin-like growth factor I receptor expression in neuroblastoma cells induces the regression of established tumors in mice. Cancer Res 1998, 58:5432-8.

21. Nahta R, Yuan LX, Zhang B, Kobayashi R, Esteva FJ: Insulin-like growth factor-I receptor/human epidermal growth factor receptor 2 
heterodimerization contributes to trastuzumab resistance of breast cancer cells. Cancer Res 2005, 65:11118-28.

22. van der Veeken J, Oliveira S, Schiffelers RM, Storm G, van Bergen En Henegouwen PM, Roovers RC: Crosstalk between epidermal growth factor receptor- and insulin-like growth factor-1 receptor signaling: implications for cancer therapy. Curr Cancer Drug Targets 2009, 9:748-60.

23. Zha J, Lackner MR: Targeting the Insulin-like Growth Factor Receptor-1R Pathway for Cancer Therapy. Clin Cancer Res 2010, 16:2512-7.

24. Scotlandi K, Picci P: Targeting insulin-like growth factor 1 receptor in sarcomas. Curr Opinion Oncology 2008, 20:419-427.

25. Scotlandi K, Manara MC, Nicoletti G, Lollini PL, Lukas S, Benini S, Croci S, Perdichizzi S, Zambelli D, Serra M, García-Echeverría C, Hofmann F, Picci P: Antitumor activity of the insulin-like growth factor-I receptor kinase inhibitor NVP-AEW541 in musculoskeletal tumors. Cancer Res 2005, 65:3868-76.

26. Toretsky JA, Gorlick R: IGF-1R targeted treatment of sarcoma. Lancet Oncol 2010, 11:105-106.

27. Scotlandi K, Benini S, Nanni P, Lollini PL, Nicoletti G, Landuzzi L, Serra M, Manara MC, Picci P, Baldini N: Blockage of insulin-like growth factor-I receptor inhibits the growth of Ewing's sarcoma in athymic mice. Cancer Res 1998, 58:4127-4131.

28. Manara MC, Landuzzi L, Nanni P, Nicoletti G, Zambelli D, Lollini PL, Nanni C, Hofmann F, García-Echeverría C, Picci P, Scotlandi K: Preclinical in vivo study of new insulin-like growth factor-I receptor-specific inhibitor in Ewing's sarcoma. Clin Cancer Res 2007, 13:1322-1330.

29. Benini S, Manara MC, Baldini N, Cerisano V, Massimo Serra, Mercuri M, Lollini PL, Nanni P, Picci P, Scotlandi K: Inhibition of insulin-like growth factor I receptor increases the antitumor activity of doxorubicin and vincristine against Ewing's sarcoma cells. Clin Cancer Res 2001, 7:1790-7.

30. Martins AS, Mackintosh C, Martín DH, Campos M, Hernández T, Ordóñez JL, de Alava E: Insulin-like growth factor I receptor pathway inhibition by ADW742, alone or in combination with imatinib, doxorubicin, or vincristine, is a novel therapeutic approach in Ewing tumor. Clin Cancer Res 2006, 12:3532-40

31. Kim WY, Jin Q, Oh SH, Kim ES, Yang YJ, Lee DH, Feng L, Behrens C, Prudkin L, Miller YE, Lee JJ, Lippman SM, Hong WK, Wistuba II, Lee HY: Elevated epithelial insulin-like growth factor expression is a risk factor for lung cancer development. Cancer Res 2009, 69:7439-48.

32. Creighton CJ, Casa A, Lazard Z, Huang S, Tsimelzon A, Hilsenbeck SG, Osborne CK, Lee AV: Insulin-like growth factor-I activates gene transcription programs strongly associated with poor breast cancer prognosis. J Clin Oncol 2008, 26:4078-85.

33. Donovan $E A$, Kummar $S$ : Role of insulin-like growth factor-1R system in colorectal carcinogenesis. Crit Rev Oncol Hematol 2008, 66:91-8.

34. Gong Y, Yao E, Shen R, Goel A, Arcila M, Teruya-Feldstein J, Zakowski MF, Frankel S, Peifer M, Thomas RK, Ladanyi M, Pao W: High expression levels of total IGF-1R and sensitivity of NSCLC cells in vitro to an anti-IGF-1R antibody (R1507) [abstract]. PLoS One 2009, 4:e7273.

35. Karp DD, Paz-Ares LG, Novello S, Haluska P, Garland L, Cardenal F, Blakely $\mathrm{L}$, Eisenberg PD, Langer CJ, Blumenschein G Jr, Johnson FM, Green S, Gualberto A: Phase II study of the anti-insulin-like growth factor type 1 receptor antibody CP-751,871 in combination with paclitaxel and carboplatin in previously untreated, locally advanced, or metastatic nonsmall-cell lung cancer. J Clin Oncol 2009, 27:2516-2522.

36. Tarn C, Rink L, Merkel E, Flieder D, Pathak H, Koumbi D, Testa JR, Eisenberg B, von Mehren M, Godwin AK: Insulin-like growth factor 1 receptor is a potential therapeutic target for gastrointestinal stromal tumors. Proc Natl Acad Sci USA 2008, 105:8387-8392.

37. Agaram NP, Laquaglia MP, Ustun B, Guo T, Wong GC, Socci ND, Maki RG, DeMatteo RP, Besmer P, Antonescu CR: Molecular characterization of pediatric gastrointestinal stromal tumors. Clin Cancer Res 2008, 14:3204-3215.

38. Pantaleo MA, Astolfi A, Di Battista M, Di Battista M, Heinrich MC, Paterini P, Scotlandi K, Santini D, Catena F, Manara MC, Nannini M, Maleddu A, Saponara M, Lolli C, Formica S, Biasco G: Insulin-like growth factor 1 receptor (IGF1r) expression in wild-type GIST: a potential novel therapeutic target. Int J Cancer 2009, 125:2991-2994.

39. Janeway KA, Zhu MJ, Barretina J, Zhu MJ, Barretina J, Perez-Atayde A, Demetri GD, Fletcher JA: Strong expression of IGF1R in pediatric gastrointestinal stromal tumors without IGF1R genomic amplification. Int J Cancer 2010, 127:2718-22.
40. Braconi C, Bracci R, Bearzi I, Bianchi F, Sabato S, Mandolesi A, Belvederesi L, Cascinu S, Valeri N, Cellerino R: Insulin-like growth factor (IGF) 1 and 2 help to predict disease outcome in GIST patients. Ann Oncol 2008, 19:1293-8.

41. Hirota S, Isozaki K, Moriyama Y, Moriyama Y, Hashimoto K, Nishida T, Ishiguro S, Kawano K, Hanada M, Kurata A, Takeda M, Muhammad Tunio G, Matsuzawa Y, Kanakura Y, Shinomura Y, Kitamura Y: Gain of function mutations of c-kit in human gastrointestinal stromal tumors. Science 1998, 279:577-580

42. Demetri $G D$, von Mehren $M$, Blanke $C D$, Blanke $C D$, Van den Abbeele $A D$, Eisenberg B, Roberts PJ, Heinrich MC, Tuveson DA, Singer S, Janicek M, Fletcher JA, Silverman SG, Silberman SL, Capdeville R, Kiese B, Peng B, Dimitrijevic S, Druker BJ, Corless C, Fletcher CD, Joensuu H: Efficacy and safety of imatinib mesylate in advanced gastrointestinal stromal tumors. N Engl J Med 2002, 347:472-480.

43. Demetri GD, van Oosterom AT, Garrett CR, Blackstein ME, Shah MH, Verweij J, McArthur G, Judson IR, Heinrich MC, Morgan JA, Desai J, Fletcher CD, George S, Bello CL, Huang X, Baum CM, Casali PG: Efficacy and safety of sunitinib in patients with advanced gastrointestinal stromal tumour after failure of imatinib: a randomised controlled trial. Lancet 2006, 368:1329-38

44. Heinrich $M C$, Corless $C L$, Demetri $G D$, Blanke $C D$, von Mehren $M$, Joensuu H, McGreevey LS, Chen CJ, Van den Abbeele AD, Druker BJ, Kiese B, Eisenberg B, Roberts PJ, Singer S, Fletcher CD, Silberman S, Dimitrijevic $S$, Fletcher JA: Kinase mutations and imatinib response in patients with metastatic gastrointestinal stromal tumors. J Clin Oncol 2003, 21:4342-9.

45. Heinrich MC, Maki RG, Corless CL, Antonescu CR, Harlow A, Griffith D, Town A, McKinley A, Ou WB, Fletcher JA, Fletcher CD, Huang X, Cohen DP, Baum CM, Demetri GD: Primary and Secondary Kinase Genotypes Correlate with the Biological and Clinical Activity of Sunitinib in Imatinib-Resistant Gastrointestinal Stromal Tumor. J Clin Oncol 2008, 33:5352-5359.

46. Dei Tos, Ellis I: Assessing epidermal growth factor receptor expression in tumours: what is the value of current test methods? Eur J Cancer 2005, 41:1383-92.

47. Mandrekar SJ, Sargent DJ: Predictive biomarker validation in practice: lessons from real trials. Clin Trial 2010, 29:1077-83.

48. Belinsky MG, Skorobogatko W, Rink L, Pei J, Cai KQ, Vanderveer LA, Riddell D, Merkel E, Tarn C, Eisenberg BL, von Mehren M, Testa JR, Godwin AK: High density DNA array analysis reveals distinct genomic profiles in a subset of gastrointestinal stromal tumors. Genes Chromosomes Cancer 2009, 48:886-96.

49. Astolfi A, Nannini M, Pantaleo MA, Di Battista M, Heinrich MC, Santini D, Catena F, Corless CL, Maleddu A, Saponara M, Lolli C, Di Scioscio V, Formica S, Biasco G: A molecular portrait of gastrointestinal stromal tumors: an integrative analysis of gene expression profiling and highresolution genomic copy number. Lab Invest 2010, 90:1285-94.

50. García-Echeverría C, Pearson MA, Marti A, Meyer T, Mestan J, Zimmermann J, Gao J, Brueggen J, Capraro HG, Cozens R, Evans DB, Fabbro D, Furet P, Porta DG, Liebetanz J, Martiny-Baron G, Ruetz S, Hofmann F: In vivo antitumor activity of NVP-AEW541-A novel, potent, and selective inhibitor of the IGF-IR kinase. Cancer Cell 2004, 5:231-9.

51. Romano G, Prisco M, Zanocco-Marani T, Peruzzi F, Valentinis B, Baserga R: Dissociation between resistance to apoptosis and the transformed phenotype in IGF-I receptor signaling. J Cell Biochem 1999, 72:294-310.

52. Pantaleo MA, Landuzzi L, Nicoletti G, Nanni C, Boschi S, Piazzi G, Santini D, Di Battista M, Castellucci P, Lodi F. Fanti S, Lollini PL, Biasco G: Advances in preclinical therapeutics development using small animal imaging and molecular analyses: the gastrointestinal stromal tumors model. Clin Exp Med 2009, 9:199-205.

53. Lorincz A, Redelman D, Horváth VJ, Bardsley MR, Chen H, Ordög T: Progenitors of interstitial cells of cajal in the postnatal murine stomach. Gastroenterology 2008, 134:1083-93.

54. Belfiore A: The role of insulin receptor isoforms and hybrid insulin/IGF-I receptors in human cancer. Curr Pharm Des 2007, 13:671-86.

55. Pantaleo MA, Nannini M, Di Battista M, Catena F, Biasco G: Combined treatment strategies in gastrointestinal stromal tumors (GISTs) after imatinib and sunitinib therapy. Cancer Treat Rev 2010, 36:63-8.

56. Rikhof B, van Doorn J, Suurmeijer AJ, Rautenberg MW, Groenen PJ, Verdijk MA, Jager PL, de Jong S, Gietema JA, van der Graaf WT: Insulin-like 
growth factors and insulin-like growth factor-binding proteins in relation to disease status and incidence of hypoglycaemia in patients with a gastrointestinal stromal tumour. Ann Oncol 2009, 20:1582-8.

57. Guiteau J, Fanucchi M, Folpe A, Staley CA, Kooby DA: Hypoglycemia in the setting of advanced gastrointestinal stromal tumor. Am Surg 2006, 72:1225-30.

58. Escobar GA, Robinson WA, Nydam TL, Heiple DC, Weiss GJ, Buckley L, Gonzalez R, McCarter MD: Severe paraneoplastic hypoglycemia in a patient with a gastrointestinal stromal tumor with an exon 9 mutation: a case report. BMC Cancer 2007, 7:13.

59. Hall KF, Lin CL, Wang TH, Chang RH, Chen HM: A case of gastrointestinal stromal tumor with hyperinsulinemic hypoglycaemia. Chang Gung Med J 2008, 31:107-11.

doi:10.1186/1479-5876-8-117

Cite this article as: Pantaleo et al:: The emerging role of insulin-like growth factor 1 receptor (IGF1r) in gastrointestinal stromal tumors (GISTs). Journal of Translational Medicine 2010 8:117.

\section{Submit your next manuscript to BioMed Central and take full advantage of:}

- Convenient online submission

- Thorough peer review

- No space constraints or color figure charges

- Immediate publication on acceptance

- Inclusion in PubMed, CAS, Scopus and Google Scholar

- Research which is freely available for redistribution

Submit your manuscript at www.biomedcentral.com/submit 